\title{
WNT4 wt Allele
}

National Cancer Institute

\section{Source}

National Cancer Institute. WNT4 wt Allele. NCI Thesaurus. Code C52999.

Human WNT 4 wild-type allele is located within 1 p36.12 and is approximately $24 \mathrm{~kb}$ in length. This allele, which encodes protein wnt-4, plays a role in embryological cell fate regulation. 